\title{
MITIGATION OF CROP RESIDUE BURNING INDUCED AIR POLLUTION IN NEW DELHI - A REVIEW
}

\author{
Gopalakrishnan Srinivasan, Arumugam Abirami \\ C P R Environmental Education Centre, \\ Chennai, India
}

\begin{abstract}
The atmosphere of New Delhi during the months of October to the January next year (every year) remains critical due to factors such as stubble burning in the nearby state of Punjab, air pollution rising out of Diwali fireworks and the smog during December and January. Stubble burning is the intentional incineration of paddy / any other field stubbles by farmers after the harvest. It is usually done to eliminate pests such as rats, crickets and hoppers. The availability of short time between rice harvesting and sowing of wheat is the most important reason for burning of crop residues. Also yield and quality of wheat gets severely affected if there is delay in sowing. Since the time gap is very limited (about $3-4$ weeks) between rice and wheat, burning of crop residues is preferred since it is the quickest and easiest solution for the farmers. According to reports, New Delhi, Noida and Ghaziabad recorded a peak Air Quality Index (AQI) of around 480 - 490 in the month of November 2019. Health effects of air pollution include respiratory diseases, skin and eye irritation and other ailments. An important factor is shortage of labor contributing to burning of rice straw. Apart from stubble burning, farmers burn wood for domestic cooking, removal of municipal solid wastes and accidental / intentional wildfires. Use of combined harvester Happy Seeder machine is a profitable and less labour-intensive management of rice residue. Yet many farmers still have the perception that there are no alternative solutions for crop residue management. Besides Happy Seeder machine, there are other machines such as rotavator, reaper binder and no-till seed drill that can be alternatives for crop residue burning. In 2019 20, the Punjab government disbursed a certain amount to farmers for not burning stubble as compensation, yet many farmers adopted the stubble burning process. Other measures such as adoption of villages by Confederation of Indian
\end{abstract}

Industries, MoU with institutes for waste management, field trials of technologies that decomposes paddy straw in the fields are also tried for the abatement of pollution. Sustainable food production is usually guided by analysis of carbon footprint and water footprint; higher the carbon and water footprint, higher the emission and pollution. There are certain management practices such as use of stubble as soil fertilizer / amendment, use of stubble as raw material in pulp and paper industries; it could be used as compost and most recently, the stubble residue is being managed by use of bio-decomposer. Biodecomposer is a solution used for spraying in the fields to convert the stubble into manure that can be beneficial for the agricultural fields. Developed by Indian Agriculture Research Institute the solution is still in testing level and is being sprayed in the agricultural lands across Punjab and Haryana.

Key words: air quality index, solid wastes, stubble burning, air pollution in New Delhi, bio-decomposer

\section{INTRODUCTION}

Indian states of Punjab, Haryana and Uttar Pradesh are together known as the 'breadbasket' of India, as is evident from the fact that majority of the IndoGangetic plains of these regions are dominated by the rice-wheat cropping system [1]. Crop stubble is an agricultural waste / organic residues that is rich in nitrogen, phosphorus and potassium. This crop stubble provides a cover that can protect the soil against water run-off and erosion [2]. Although it has several advantages, due to lack of awareness, majority of the agricultural community in Punjab and Haryana are inclined only to the burning of stubble for the next sowing. Due to wind action, the smoke that arises from these paddy fields move towards the National Capital Region New Delhi. Stubble burning 
results in emissions of toxic gases, airborne particulate matter and heavy metals that lead to pulmonary ailments of local farming communities [35]. A number of researches have been done and experimental steps have been taken in addressing the air pollution, yet there is no solid solution. Stubble burning is perceived to be the quickest and economic way to prepare the fields for next cropping cycle by the farmers and it is still in practice even though the same farmers are very much aware of the air pollution problem that reflect in New Delhi. Apart from disease burden and air pollution, stubble burning also causes steady increase of higher concentration of short lived climate pollutants (SLCP) [6]. Studies have revealed that gaseous emissions from stubble burning may be around 110 , 2306, 2 and $84 \mathrm{Gg}$ (Gigagram) respectively for methane, carbon monoxide, nitrous oxide and nitrogen dioxide [7]. Unsystematic and random ploughing, use of excessive use of chemical fertilizers, stubble burning and many other issues lead to deterioration of soil and atmosphere and key parameters such as soil organic carbon, soil biodiversity, runoff, loss of nutrients, carbon and water, soil resilience and ecosystem services [8-10]. Burning of rice straw results in losses in soil nutrients, soil organic matter, decrease in productivity, and negative impact on air quality, biodiversity, energy efficiency and impact on human and animal health [11].

Stubbles / Crop residues are cellulosic material with carbon content, a source for energy generation having direct impact on soil carbon sequestration, quality maintenance and ecosystem utilities [12]. Technological mitigation measures such as biomass energy generation, biochar and composting, zero tillage measures, use of bio-decomposer, use of hybrid seeds, use of crop residue as nutrient for livestock, subjecting agro byproducts to production of value added products, use of bioinoculuants etc and non-technological mitigation measures such as mixed crop production, awareness and education about promotion of alternative use of crop residue are also considered [13]. Although New Delhi is choked with vehicular emissions, burgeoning municipal solid wastes, construction and demolition wastes throughout the year, air pollution arising due to stubble burning has a larger impact as the crop residues in Punjab, Haryana and Uttar Pradesh are burnt exactly during the post-monsoon period, i.e. October and November. The present review article is an attempt to highlight the eco-friendly / organic measures take to mitigate the stubble-burning induced air pollution in New Delhi.

\section{Biomass burning}

Open-air burning of wastes such as dried leaves, agricultural residues, municipal solid wastes and other biodegradable wastes is a common practice in many regions worldwide. Although it is being practiced since time immemorial, at present, due to the combined effect of open-air burning induced air pollution and vehicular emissions, it has a major impact in the greenhouse effect. Urban agglomeration, land conversion, monsoon failure, crop failure, increasing population, limited availability of natural resources and certain other factors lead to unpredictable revenue through agriculture. In many of the western countries, there are certain alternative techniques to avoid open-air burning of biomass residue; also there is very limited to nil impact in change of air quality over a period of time, due to population density. But in countries like India and China, where the population density is high, there is a severe impact in quality of air as a result of increased vehicles usage and emissions. For e.g., a study undertaken in Portugal [14] revealed that smoke from the open burning of trees' branches revealed the emissions of particulate matter, organic carbon and elemental carbon in the ranges of $8.7-$ $20.1,2.7-7.4$ and $0.3-1.1 \mathrm{~g} / \mathrm{kg}$ biofuel; also variations with biofuel burned with respect to smoke particles that contained acids, phenolic compounds, sterols and polyols was also reported. Had the study been carried out in terms of Indian scenario, the values would have been much higher. Another study [15] reported that aerosol transport during 2018 2019 affected the air quality of Bangkok severely. The concentration of $\mathrm{PM}_{2.5}$ during haze and non-haze period was studied. The average $\mathrm{PM}_{2.5}$ concentrations during haze periods were higher than in non-haze periods, showing the impact of climate on the air pollution and associated human health. The main contributions were from biomass combustion, thermal inversions and weak winds. Similarly there is steady increase in health issues during the postmonsoon period of October - December, where there is significant fog early in the morning in New Delhi. A study using satellite data [16] to detect the agricultural residue burning estimated the impact of air pollution and the cardiorespiratory diseases in China; it reported that approximately $10 \mu \mathrm{g} / \mathrm{m}^{3}$ increase in $\mathrm{PM}_{2.5}$ increases mortality rate in middleaged and old people in rural areas. The burning of biomass and its emissions have impact as far as on Tibetian Plateau, specifically during the pre-monsoon 
seasons, suggests a study [17]. An optimized tracerbased approach was used for estimating the impact of biomass burning on atmospheric particulate matter of $\mathrm{PM}_{2.5}$ in Mongolia; nearly $68 \%$ of the organic carbon was emitted from biomass burning during winter season. In addition to this, sources apart from biomass burning that contributed to atmospheric pollution were coal burning, vehicular emissions and vegetative emissions [18].

Agriculture, as described since time immemorial, is 'the backbone of Indian economy'. Approximately $500-550$ million tons of crop residue is generated on-farm and off-farm annually from its production of $110 \mathrm{Mt}$ of wheat, $122 \mathrm{Mt}$ of rice, $71 \mathrm{Mt}$ of maize, 26 Mt of millets, $141 \mathrm{Mt}$ of sugarcane, $8 \mathrm{Mt}$ of fibre crops and $28 \mathrm{Mt}$ of pulses [19]. Farming system in Indo-Gangetic Plain area is rice-wheat rotation system. Most of the farmers prefer combine harvesting process for planting and harvesting the crops that generate significant amount of crop waste residue or stubble. Since the machine reduces manual efforts and labour charges and performs the three main tasks - reaping, threshing and winnowing in a single operation, it is preferred in most parts of India. If the crop residue is smaller and twig-like grains, they can be easily incorporated into the soil. But if it is lengthy as high as $15-20 \mathrm{cms}$, it is difficult and hence the farmers prefer to burn it for next round of cultivation [20-22]. The issue of stubble burning by farmers in Punjab, Haryana and Western Uttar Pradesh and its environmental impact has gained importance from 2015 - 2016. National Green Tribunal banned stubble burning in the states of Rajasthan, Uttar Pradesh, Haryana and Punjab in 2015. Penalty against defaulters were imposed, but still it is being carried out. According to a study in 2012, stubble burning releases nearly 150 million tonnes of carbon dioxide, 9 million tonnes of carbon monoxide, 0.25 million tonnes of SOX, 1.3 million tonnes of particulate matter and almost 1 million tonnes of black carbon [23]. A hazy atmosphere is observed during the winter season and it is linked to stubble burning. During this time, most Indian cities experience severe air pollution and the air quality index usually shows severe to very severe in and around New Delhi [24]. A study involving the public preferences for setting up a biomass based power plant to end the practice of open field burning, 'willingness to pay' by the farmers revealed that providing employment and training opportunities for locals, reducing the health risks associated with burning of biomass were the major areas of concern [25]. In case of rice, the residue includes straw and husk. Every ton of paddy generates around 1 million ton of straw and 0.2 million ton of husk. In case of wheat, the main residue is straw and 1 ton of wheat produces equal amount of straw. Stover, cob and silk are the residues of maize. Every ton of maize generates 1.5 million ton of stover and 0.2 million ton of husk and silk.

\section{Crop waste management - alternate methods}

2.1. Conversion of large-scale agro-industrial processing wastes into manure / useful byproducts is a valuable option. Since the agricultural residues are free of nonbiodegradable wastes, instead of burning, they can efficiently turned into manure and value added products. They can be used in the production of green energy [26]. This newer technique of turning waste into wealth is in order to maintain sustainability, depletion of resources, and use of solid wastes as biomass for bioenergy. Another option is solid state fermentation of agro-industrial wastes. A study [27] reported the conversion of sugarcane bagasse, orange pulp and peel and wheat bran into enzymes. Mixing of wed biomass, crop residue in various ratios (50:50, 50:100) in plots and various sub-plots along with microbes such as Trichoderma viridi and Pleurotus sp as spawn seeds resulted in increased yield, improvement in soil $\mathrm{pH}$, nitrogen, phosphorus, potassium and soil organic carbon and overall crop productivity and also aiding in environmental sustainability [28]. A study estimated the bioresources from arable field crops, livestock products and residues to convert them into useful byproducts; rice straw and husk, rubber residues and cattle manure has been estimated to provide a considerable share of energy supply in Thailand [29]. In a study in South Korea, soil enzyme activity due to supplement of green manure (crop residue along with amendments) was tested in submerged rice cropping system; increased enzyme activity was observed; also it increased the composition of microbial groups, microbial biomass and enzyme activities of the soil [30]. In a study in South Africa, conventional tillage, crop rotation and residue management influenced the enzyme activity in soil and indicated that tillage and residue management were the main factors influencing soil biological indicators; also there was significant difference in soil biological indicators under non-tillage and retention of residue [31]. This process of biotillage promotes 
root growth by providing oxygen and nutrients. On the other hand, crop rotation has significant effects on soil quality index than residue management, proves a study in South Africa, where crop rotation and residue management effects were observed for soil quality [32]. 'Conservation Agriculture' strategy can be adopted wherein soil disturbance is minimal with retention of residue for the soil cover. In India, conventional farming methods, weeds can be controlled by tillage operations; conservation agriculture also reduces weeds by manual weeding and use of herbicides [33]. Plants such as Guinea grass, Khuskhus and Bhabar have been used as 'vegetation strips' in Shivalik hills [34]. They act as an effective barrienr against erosion and sediment control as they form an erect, stiff and dense hedge to prevent overland water flow. Also they provide economic benefits to farmers (Khuskhus). Certain other strategies such as mowing, rolling, roll-chopping, undercutting and rototilling are followed for the management of crop residues. Cover-crop residues are at times left on the soil surface as a mulch; these protect the soil from erosion, increase water infiltration and suppress weeds. This is mainly done to reduce the chemical methods followed [35]. Biofuel generation from non-food feedstocks such as agricultural wastes, forest wastes, crop residues etc is another option in management. A study reports that application of biological pretreatment and anaerobic digestion of crop residues will be effective than applying as such to the plants [36]. Another study assessed the short-term and long-term effects of sugarcane burning on soil organic matter characteristics; burning of sugarcane field, renewal of sugarcane field with the application of vinasse and combination of both. The results showed that application of vinasse preserved and restored the soil from fire effects. Reduction in organic carbon, particulate organic carbon, humic acid and organic matter affected due to fire later recovered by the application of vinasse [37]. There are reports of thermochemical conversion of crop residues of cotton bol, soybean hust and mustard husk and straw to recover syngas and potassium-based fertilizer [38]. Usually biomass is converted into ethanol in several steps: pre-treatment to remove lignin and hemicelluloses, enzymatic breakdown of cellulosic wastes to sugars, c. fermentation for ethanol production and d. purification of ethanol and byproducts [39].
2.2. Application of Biochar or Arbuscular mycorrhizal fungi or combination of both and that of bacteria to the soil has been tested and reported for their role in carbon sequestration. This is one of the green restoration process using biochar coupled with AMF, which has been suggested as a suitable and sustainable option. Further it has been reported that their coupled application could lead to an increase in biomass productivity, crop performance and soil quality, root zone system, overall surface area for the retention of water and nutrients, reduces the dependence on chemical fertilizers [40]. In another study, application of Sesbania greenmanure, mustard-residue and fertilizers over soil was conducted for a period of five years; Sesbania green manure increased the soil organic carbon, rate of carbon sequestration potential, soil permeation rate, NPK status as evident from the increase of plant height, branches, seeds and seed and oil yield when compared to fallowmustard practice [41]. Yet another study carried out vermicomposting of crop residues with earthworms - Eisenia foetida; mustard residues, sugarcane trash and cattle dung were treated with earthworms in various lots of mixing concentrations. The study also indicated that crop residues can be converted into vermicompost when mixed with cattle dung [42]. Eudrilus eugeniae can also be used for vermicomposting of crop residues - Paddy straw, maize stover, leaf litter, vegetable wastes and temple waste flowers as reported in a study; the mature vermicompost was microbiologically active in terms of population and enzyme activities [43]. In another study [44], waste corn biomass was used to prepare phosphate biofertilizer by adsorbing phosphorus from source-separated urine. The biochar obtained was modified with magnesium and its performance was compared with the one without magnesium modification. This was done to analyze the phosphate adsorbing capacity of the obtained biochar. Apart from application to plants, the biochar was also used for disinfection of pathogen with efficiency of nearly $80 \%$. Presence of high amounts of biochemical energy in the form of cellulose and lignin in crop residues is an additional advantage. This biomass could be used for conversion to bioenergy. Conversion of lignocellulosic biomass in a microbial fuel cell with the addition of rumen fluid can also be achieved. Combination of 
residues of two or three plants as 'green manure biomass' on rice crops can increase the yield and the microbial activity than inorganic fertilizers. Green manure incorporated microbes can increase the enzyme activity, Nitrogen, Phosphorus and Carbon cycling in the soil. Torrefaction of fruit peels at different temperatures for different durations yield biochar as a renewable energy. Torrefaction temperature has an influence on the characteristics of the biochar. This can further reduce the greenhouse gas emissions and replacing coal in power plants [45]. Soil microbial nitrate immobilization is improved by plant residue application. This in turn, reduces nitrate accumulation and reduces nitrogen losses. Both fungal and bacterial nitrate immobilization increased after the addition of residue of a novel grass. Increased residue inputs, microbial community composition and nitrate immobilization are inter-related and have impact on the property of crop residue waste [46]. Use of cellulolytic nitrogen-fixing bacteria for composting for lignocellulosic crop residue is in research level and has promising results in crop residue management, with good quality compost as byproduct. Also the cellulose degrading and nitrogen-fixing property of bacteria could aid in rapid composting, enhancement of soil fertility besides plant growth and sustainable management of lignocellulosic crop residue [47]. Compost can be employed either alone or in combination of fungi, protists, oomycetes, yeast, actinomycetes and bacteria, acting as biological control agents by fitting the soil quality and plant health [48]. Use of nitrogen-based chemical fertilizers has already lead to environmental destruction, which can be alleviated by ecofriendly strategies such as use of nitrogen-fixing bacteria - Rhizobium, Pseudomonas, Azospirllium and Bacillus. These enhance both above and belowground biomass and hence sustainable agricultural practices are achieved [49].

2.3. Use of straw, happy seeder machine and notill farming and promotion of hybrid seeds: Soil organic matter can be retained by incorporation of crop straw into the soil. Apart from this, water retention is achieved; plays an important role in maintaining soil structure and nutrient cycles [13]. This also improves soil fertility as it contains the natural NPK. Along with this, inorganic nitrogen or microbial inoculation can also be tried for better management. This method does not need any artificial nutrients or chemicals as fertilizers. Since there is no proper machinery apart from happy seeder, still this process is labor-intensive and time consuming. The no-till farming is usually recommended for sowing of crops. It helps in maintaining the organic matter; the humus that is already present consists of nutrients and acts as compost for the crop. To achieve a significant yield, weather conditions, soil water evaporation and water availability are the factors to be considered. Studies show that incorporation of straw and tillage practices could increase yield when compared with traditional practices, which is labor-intensive. No-till farming also reduces the production costs of grains and also enhances soil carbon sequestration capacity and increases crop yield [50]. Happy seeder or Turbo Happy Seeder is a tractor-operated machine for in-situ management of paddy stubble. Happy Seeder machines can be used as there is little to no disturbance to the topsoil to sow the seeds. Also the machine helps in mulching, seed drilling (dual purpose); there are reports of higher yield of wheat when Happy seeder machine is used when compared with conventional tillage. Of late, there are issues from certain quarters of the farmers: There is no guarantee for increased yield and the yield is at par with the conventional tillage methods; the machine does not work on thick bunches of straw left behind. Also there is general notion that increase of wheat yield will be higher only after 2 to 3 years as the stubble will augur the organic content of the soil. Government of Punjab provides subsidies for the farmers, yet due to these issues, many are hesitant to use the machine. Hybrid seeds have shorter growing period and produces less crop residue. Apart from this, the crop residue is used as fodder for the livestock. In some cases, the fodder is also modified as processed feed before it is given to livestock [51]. Apart from these, paddy-straw chopper, RMB plough, Mulcher, Super SMS, Cutter-cum-spreader, rotary slasher, Super Seeder, Shrub Master, etc. are other machines sanctioned by the Government of Punjab.

\subsection{Use of bio-decomposer, organic decomposing} solution is a viable for crop residue management. National Centre for Organic Farming has developed the waste decomposer culture that degrades the organic waste as well as improves soil health acting as protection agent. It 
is a consortium of microorganisms extracted from cow dung. To meet the regular requirement, mother culture strains of different microorganisms for production of biofertilizers has to be maintained. Nearly $200-250$ strains of microorganisms and periodical sub culturing in $\mathrm{lab}$ is required. The starter culture for the decomposer solution includes $2 \mathrm{~kg}$ of jaggery mixed in 2001 of water in a container. 1 bottle of the waste decomposer (nearly $30 \mathrm{~g}$ ) is added into the container and mixed properly. This is to be stirred with a wooden log daily once or twice. After 5-6 days, when the solution turns creamy, it is ready for use. 1 ton of the compost is spread over a plastic sheet placed under shade. 201 of the solution is sprinkled over the compost layer and another layer of compost over the existing layer. Again the solution is sprinkled and a layer of compost is added. This is to be carried out for $10-12$ layers. $60-65 \%$ moisture is to be maintained. The compost is to be turned over at 7 days interval. After $35-40$ days, it is ready to use. This compost is dark brown in color, without malodour, dry and contains high amount of organic carbon and other nutrients. If it is prepared in the appropriate way, it should not attract flies, insects and foul smell. Normal vermicomposting and night soil composting may lead to foul smell like rancid butter, ammonia, attracts rodents, flies or other animals etc. But in the case of waste decomposer, there is very little to nil reports of offensive odour and recurring supervising problems.

The waste decomposer is also used as a biopesticide, in in-situ composting of crop residue, drip irrigation (partial mixture, fertigation), seed treatment, foliar spray etc. It has the potential to control certain diseases in chilli, tomato, brinjal, crop quality, improvement in soil salinity, seed germination, control of root borne diseases and overall soil physicochemical and biological properties [52]. A study [53] used residues of cover crop monocultures and mixtures of bacterial and fungal biomass to test the microbial diversity, metabolic potential and greenhouse gas emissions; it reported that emissions of nitrous oxide and carbon dioxide were significant. There was a considerable increase in fungal biomass, no differences in cover crop mixtures and monocultures; overall mixtures of cover crops stimulated the microbial activity.

Using plant roots as a tillage tool to alter the structure of soil is also being carried out to obtain favorable conditions for crop growth. This process of altering is called Biotillage [54]. Main advantages of this is thick-root plants are effective in improving soil structure through plant roots, creating channels during plant growth and then decomposing to leave open biopores, which in turn could transport air and water and improves soil aeration capacity and reduces surface runoff and erosion. Besides this, the bipores provides pathways for root penetration. Biotillage is usually carried out using cover crops (close-growing crops planted between periods of normal crop production). Usually they are grown to mitigate soil erosion, suppressing weeds and pests, nitrogen fixation, improving soil fertility, mitigation of soil compaction and improving soil structure [55]. Climatic conditions and management practices affects the benefit of biotillage. There is another report that use of cover crops on con yield decreased for legume species but there was an increase if a combination of legume and non legume species, if the supplementary nitrogen fertilizer is applied in larger amount. However, in India, there is very little information in use of cover crops in paddy fields and wheat fields and their effect on crop waste management. Other alternate uses such as using rice residue as fodder for cattle, for making biogas, for mushroom cultivation and incorporation of paddy straw in soil for mulching etc. are also reported; this may have a good yield of maize, soybean and sugarcane crops and a significant savings in terms of irrigation and fertilizers [56]. Sono-assisted (use of clean, rapid method for elimination of toxins and recovery of useful products) adsorption / Sonoassisted pretreatment for removal of lignin and hemicelluloses and to improve the sugar yield from residues are also reported; The biomass, before and after pretreatment with acids has been reported to yield sugars on enzymatic hydrolysis. Fermentation of the hydrolysate yielded bio-ethanol [57].

In 2020, application of Biodecomposer (product containing strains of bacteria and fungus) developed by Indian Agricultural Research Institute, Pusa has been tested over the crop residues. It contains dormant form of decomposing bacteria and cell mass of fungal spore. This induces the decomposition of biomass both under aerobic and anaerobic conditions. The product is an aqueous suspension capable of decomposing organic raw materials, crop residue and animal wastes etc. It produces carbon dioxide, ammonia, water, heat and manure. Usually the time taken for decomposition is around 2 months. This solution breaks down the proteins, fats and complex hemicelluloses and lignocellulosic carbohydrates. 
When this mixture is applied over the organic matter / heap of crop residue, it gets activated and multiplies its number of cells. They utilize the carbon source and secrete enzymes that break down the complex organic material into simpler forms. The bacterial base and fungal base are usually packed in separate containers. While application, both has to be mixed in sufficient quantity of water - either in drum or container and sprayed over the heap of organic material of around one metric ton. After $10-12$ days, the heap has to be turned and the solution has to be sprayed again and the heap has to be mixed thoroughly. This has to be kept undisturbed for around 2 months. After this period, it has to be dried under sunlight for a few days. After this process, the compost is ready for use. The finished product is non-toxic, cost-effective, less labour-intensive and less time consuming. Also there are no rodent and residue problems. Since this is a new process, farmers' perception, patronage and the product's success in field level are yet to be studied.

\section{Conclusion}

Imposing a blanket ban on stubble burning is not fruitful unless the farming community is made clear about its ill effects on human, animal and soil health. Use of crop residues as bio-fertilizers has a positive impact on soil such as improvement of organic carbon content, soil water holding capacity, water percolation and overall soil nature. Lifecycle assessment is the need of the hour to analyze the environmental sustainability of crop residues. Crop residues are available all round the year, which can be subjected to valorization / torrefaction for energy recovery. Evaluation of ecological, social and economic sustainability of energy generation from crop residues is to be analyzed for better utilization. Plant based waste feed stocks are used as raw materials for production of bio-ethanol. Most of the methods follow the fermentation in cane syrup and corn wastes. Crop residues contain cellulosic materials, stocks of starch (in case of corn), sucrose (from sugarcane bagasse or sugar beet), vegetable wastes, oil cakes and food and yard wastes. Bioethanol produced from these wastes are promising solutions as an alternative for conventional production of ethanol. Policy-level decision is to be taken for reduction of fossil fuel consumption. Studies have reported that proper management of crop residues of wheat straw, rice straw, rice bran, rice husk and corn straw can render them as feed for worms, in turn, their frass can be used for the production of biochar. Surveys of water footprint, carbon footprint, and actual consumption of water for irrigation, greenhouse gas hotspots in and around Indo-Gangetic plain area are considered for minimization of air pollution. Studies indicate that before conducting any survey, the management practices, resource consumption, variation in carbon footprint and water footprint, farmers' preferences in management practices, their literacy should also be considered. Extension education about the value of biomass is to be disseminated among the growers and producers. In some cases, farmers are aware of the value of biomass and are willing to spend for commissioning of biomass-based power plant to combat open-field burning; factors considered before setting up are economic benefits, revenue for farmers, employment opportunities for local youth and transport. Though burning of crop residues may have short-term benefits, the adverse effects on soil health and long term health hazards in and around New Delhi are usually ignored. Liquid compositions of crude compost-based solutions or tailored mixtures of plant-based acids, macro and micronutrients and endogenous microbiota have shown many benefits for plant growth and crop health. More research is needed to understand the implications of farm laws on crop residue burning and the associated risks. There is a general perception that Diwali and other major festivals are to be celebrated by burning crackers. In no religious texts it is mentioned that major festivals are to be celebrated in a way that pollutes the environment. Yet, for human pleasure, it is still followed. There are restrictions placed for bursting of crackers during Diwali days that are sparsely followed by the revelers. Combined effect of stubble burning and cultural practices of celebrating the festivals during October - December months will take a toll on the health and environment in the coming years. Strict adherence to laws, stringent actions against the defaulters in case of polluters is the need of the hour. Intensive research is in place for management of crop residue, yet, without the cooperation of farming communities and general public, stubble burning related air pollution cannot be mitigated overnight.

\section{Conflict of interest}

The authors declare that there is no conflict of interest.

\section{References}

[1] Kumar V., Jat H.S., Sharma P.C., Singh B., Gathala M.K., Malik R.K., Kamboj B.R., Yadav A.K., Ladha J.K., Raman A., Sharma D.K. and 
McDonald A. (2018). "Can productivity and profitability be enhanced in intensively managed cereal systems while reducing the environmental footprint of production? Assessing sustainable intensification options in the breadbasket of India". Agriculture, Ecosystems and Environment, 252, (pp. $132-147)$.

[2] Huang G.B., Luo Z.Z., Li L.L., Zhang R.Z., Li G.D., Cai L.Q. and Xie J.H. (2012). "Effects of stubble management on soil fertility and crop yield of rainfed area in Western Loess Plateau, China". Applied and Environmental Soil Science, (pp. 1 -9).

[3] Agarwal R., Awasthi A., Singh N., Gupta P.K., Mittal S.K. (2012). "Effects of exposure to rice-crop residue burning smoke on pulmonary functions and oxygen saturation level of human beings in Patiala (India)". Science of the Total Environment, 429, (pp. $161-166)$.

[4] Awasthi A., Singh N., Mittal S., Gupta P.K., Agarwal R. (2010). "Effects of agriculture crop residue burning on children and young on PFTs in North West India". Science of the Total Environment, 408 (20), (pp. 4440 - 4445).

[5] Lopes A.A., Viriyavipart A. and Tasneem D. (2020). "The role of social influence in crop residue management: Evidence from North India". Ecological Economics, 169, (pp. 1 - 13).

[6] Dey D., Gyeltshen T., Aich A., Naskar M. and Roy A. (2020). "Climate adaptive crop-residue management for soil-function improvement; recommendations from field interventions at two agro-ecological zones in South Asia". Environmental Research, 193, (pp. 1-9).

[7] Badarinath K.V.S, Chand T.K. and Prasad V.K. (2006). "Agriculture crop residue burning in the Indo-Gangetic Plains - A Study using IRS-P6 AWiFS satellite data". Current Science, 91(8), (pp. 1085 - 1089).

[8] Montgomery D.R. (2007). "Soil erosion and agricultural sustainability". Proceedings of National Academy of Sciences, 104, (pp. 13268 - 13272).

[9] Lal R. (2015). "Restoring soil quality to mitigate soil degradation". Sustainability, 7(5), (pp. 5875 5895).

[10] Saurabh K., Rao K.K., Mishra J.S., Kumar R., Poonia S.P., Samal S.K., Roy H.S., Dubey A.K., Choubey A.K., Mondal S., Bhatt B.P., Verma M. and Malik R.K. (2021). "Influence of tillage based crop establishment and residue management practices on soil qualiy indices and yield sustainability in ricewheat cropping system of Eastern Indo-Gangetic Plains". Soil and Tillage Research, 206, (pp. 1-9). [11] Pandey R., Kedia S. and Malhotra A. (2020). "Addressing Air quality spurts due to crop stubble burning during Covid-19 pandemic: A case of Punjab". National Institute of Public Finance and Policy - Working Paper

[12] Prasad S., Singh A., Korres N.E., Rathore D., Sevda S. and Pant D. (2020). "Sustainable utilization of crop residues for energy generation: A life cycle assessment (LCA) perspective". Bioresource Technology, 303, (pp. 1 - 12).

[13] Ravindra K., Singh T. and Mor S. (2019). "Emissions of air pollutants from primary crop residue burning in India and their mitigation strategies for cleaner emissions". Journal of Cleaner Production, 208, (pp. 261 - 273).

[14] Alves C.A. , Vicente E.D., Evtyugina M., Vicente A., Pio C., Amado M.F., Mahia P.L. (2019). "Gaseous and speciated particulate emissions from the open burning of wastes from tree pruning". Atmospheric Research, 226, (pp. 110-121).

[15] Dejchanchaiwong R., Tekasakul P., Tekasakul S., Phairuang W., Nim N., Sresawasd C., Thongboon K., Thongyen T. and Suwattiga P. (2020). "Impact of transport of fine and ultrafine particles from open biomass burning on air quality during 2019 Bangkok haze episode". Journal of Environmental Sciences, 97, (pp. 149 - 161).

[16] He G., Liu T., Zhou M. (2020). "Straw burning, PM2.5 and death: Evidence from China". Journal of Development Economics (in press).

[17] Yang J., Ji Z., Kang S. and Tripathee L. (2021). "Contribution of South Asian biomass burning to black carbon over the Tibetian Plateau and its climatic impact". Environmental Pollution, 270 (in press).

[18] Nirmalkar J., Batmunkh T. and Jung J. (2020). "An optimized tracer-based approach for estimating organic carbon emissions from biomass burning in Ulaanbaatar, Mongolia". Atmospheric Chemistry and Physics, 20, (pp. 3231 - 3247).

[19]Devi S., Gupta C., Jat S.L. and Parmar M.S. (2017). "Crop residue recycling for economic and environmental sustainability: The case of India". Open Agriculture, 2 (pp. 486 - 494).

[20] Sharma A.R., Kharol S.K., Badarinath K.V.S., Singh D. (2010). "Impact of agriculture crop residue burning on atmospheric aerosol loading - a study over Punjab State, India". Annals of Geophysics, 28(2), (pp. $367-379$ ).

[21] Mittal S.K., Singh N., Agarwal R., Awasthi A., Gupta P.K. (2009). "Ambient air quality during wheat and rice crop stubble burning episodes in Patiala". Atmospheric Environment, 43(2), (pp. 238 244).

[22] Pratika C., Sandhu H.A.S. (2020). "Stubble burn area estimation and its impact on ambient air quality 
of Patiala and Ludhiana District, Punjab, India". Heliyon 6(1) (in press).

[23] Indian Agricultural Research Institute (2012). Crop residues management with conservation agriculture: Potential, constraints and policy needs.

[24] Abdurrahman M.I., Chaki S. and Saini G. (2020). "Stubble burning: Effects on health and environment, regulations and management practices". Environmental Advances 2, (pp. 1 - 12).

[25] Kaur S. (2020). "Public preferences for setting up a biomass power plant to combat open-field burning of rice crop residues: A case study of district Sangrur, Punjab, India”. Biomass and Bioenergy, 138 (in press).

[26] Souto B.A., Souza V.L.C., Perazzini M.T.B. and Perazzini H. (2021). "Valorization of acai bio-residue as biomass for bioenergy: Determination of effective thermal conductivity by experimental approach, empirical correlations and artificial neural networks". Journal of Cleaner Production (in press).

[27]Casciatori F.P., Laurentino C.L., Lopes K.C.M., de Souza A.G. and Thomeo J.C. (2013). "Stagnant effective thermal conductivity of Agro-industrial residues for solid-state fermentation". International Journal of Food Properties, 16: (pp. 1578 - 1593).

[28] Choudhary V.K., Gurjar D.S. and Meena R.S. (2020). "Crop residue and weed biomass incorporation with microbial inoculation improve the crop and soil productivity in the rice (Oryza sativa L.) - toria (Brassica rapa L.) cropping system". Environmental and Sustainability Indicators (in press).

[29] Wang W., Porninta K., Aggarangsi P., Leksawasdi N., Li L., Chen X., Zhuang X., Yuan Z. and Qi W. (2021). "Bioenergy development in Thailand based on the potential estimation from crop residues and livestock manures". Biomass and Bioenergy, 144 (in press).

[30] Khan M.I., Gwon H.S., Alam M.A., Song H.J., Das S. and Kim P.J. (2020). "Short term effects of different green manure amendments on the composition of main microbial groups and microbial activity of a submerged rice cropping system". Applied Soil Ecology, 147 (in press).

[31] Malobane M.E., Nciizah A.D., Nyambo P., Mudau F.N. and Wakindiki I.I.C. (2020). "Microbial biomass carbon and enzyme activities as influenced by tillage, crop rotation and residue management in a sweet sorghum cropping system in marginal soils of South Africa". Heliyon, 6(11) (in press).

[32] Gura I. and Mnkeni P.N.S. (2019). "Crop rotation and residue management effects under no till on the soil quality of a Haplic Cambisol in Alice,
Eastern Cape, South Africa". Geoderma, 337, (pp. 927 - 934).

[33] Chauhan B.S., Mahajan G. (2012). "Role of integrated weed management strategies in sustaining conservation agriculture system". Current Science, 103(2), (pp. 135 - 136).

[34] Ghosh B.N., Dogra P., Sharma N.K., Bhattacharyya R. and Mishra P.K. (2015). "Conservation agriculture impact for soil conservation in maize-wheat cropping systems in the Indian sub-Himalayas". International Soil and Water Conservation Research, 3, (pp. 112 - 118).

[35] Creamer N.G., Dabney S.M. (2009). "Killing cover crops mechanically: review of recent literature and assessment of new research results". American Journal of Alternative Agriculture, 17(1), (pp. 32 40).

[36] Dar R.A., Parmar M., Dar E.A., Sani R.K., Phutela U.G. (2021). "Biomethanation of agricultural residues: Potential, limitations and possible solutions". Renewable and Sustainable Energy Reviews, 135 (in press).

[37] Dos Santos O.A.Q., Tavares O.C.H., Garcia A.C., Rossi G.C.Q., de Moura O.V.T., Pereira W., da Silva L.A.R., Berbara R.L.L. and Pereira M.G. (2020). "Fire lead to disturbance on organic carbon under sugarcane cultivation but is recovered by amendment with vinasse". Science of the Total Environment (in press).

[38] Muller F., Patel H., Blumenthal D., Pozivil P., Das P., Wieckert C., Maiti P., Maiti S. and Steinfeld A. (2018). "Co-production of syngas and potassium based fertilizer by solar-driven thermochemical conversion of crop residues". Fuel Processing Technology, 171, (pp. 89-99).

[39] Kasaai M.R. (2018). "Conversion of renewable and food wastes into useful products with environmental perspectives". Encyclopedia of Renewable and Sustainable Materials, 4, (pp. 413 424).

[40] Gujre N., Soni A., Rangan L., Tsang D.C.W., Mitra S. (2020). "Sustainable improvement of soil health utilizing biochar and arbuscular mycorrhizal fungi: A review". Environmental Pollution (in press). [41] Premi O.P., Kandpal B.K., Rathore S.S., Shekhawat K., Chauhan J.S. (2013). "Green manuring, mustard residue recycling and fertilizer application affects productivity and sustainability of Indian mustard (Brassica juncea L.) in Indian semiarid tropics". Industrial Crops and Products, 41, (pp. $423-429)$.

[42] Bansal S., Kapoor K.K. (2000). "Vermicomposting of crop residues and cattle dung 


\section{International Journal of Engineering Applied Sciences and Technology, 2020 Vol. 5, Issue 8, ISSN No. 2455-2143, Pages 282-291 \\ Published Online December 2020 in IJEAST (http://www.ijeast.com)}

with Eisenia foetida”. Bioresource Technology, 73, (pp. 95 - 98).

[43] Pandit L., Sethi D., Pattanayak S.K. and Nayak Y. (2020). "Bioconversion of lingo-cellulosic organic wastes into nutrient rich vermicompost by Eudrilus eugeniae”. Bioresource Technology Reports (in press).

[44] Jena J., Das T., Sarkar U. (2020). "Explicating proficiency of waste biomass-derived biochar for reclaiming phosphate from source-separated urine and its application as a phosphate biofertilizer". Journal of Environmental Chemical Engineering (in press).

[45] Lin Y., Zheng N., Hsu C. (2020). "Torrefaction of fruit peel waste to produce environmentally friendly biofuel". Journal of Cleaner Production (in press).

[46] Li X., Li Z., Zhang X., Xia L., Zhang W., Ma Q. and He H. (2020). "Disentangling immobilization of nitrate by fungi and bacteria in soil to plant residue amendment". Geoderma, 374 (in press).

[47] Harindintwali J.D., Zhou J. and Yu X. (2020). "Lignocellulosic crop residue composting by cellulolytic nitrogen-fixing bacteria: A novel tool for environmental sustainability". Science of the Total Environment, 715, (pp. 1-13).

[48] Corato U.D. (2020). "Agricultural waste recycling in horticultural intensive farming systems by on-farm composting and compost based tea application improves soil quality and plant health: A review under the perspective of a circular economy". The Science of the Total Environment (in press).

[49] Igiehon N.O., Babalola O.O. (2018). "Rhizosphere Microbiome modulators: Contributions of Nitrogen Fixing bacteria towards sustainable agriculture". International Journal of Environmental Research and Public Health, 15(4): 574, (pp. 1 - 25). [50] Song K., Yang J., Xue Y., Lv W., Zheng X. and Pan J. (2016). "Influence of tillage practices and straw incorporation on soil aggregates, organic carbon and crop yields in a rice-wheat rotation system". Scientific reports, 6, (pp. 1-12).

[51] Na Y.J., Lee I.H., Park S.S., Lee S.R. (2014). "Effects of combination of rice straw with alfalfa pellet on milk productivity and chewing activity in lactating dairy cows". Asian - Australasian Journal of Animal Science, 27, (pp. 960 - 964).

[52]

http://ncof.dacnet.nic.in/AnnualReports/AnnualRepor t2017-18.pdf

[53] Drost S.M., Rutgers M., Wouterse M., de Boer W. and Bodelier P.L.E. (2020). "Decomposition of mixtures of cover crop residues increases microbial functional diversity". Geoderma, 361 (in press).

[54] Zhang Z. and Peng X. (2021). "Bio-tillage: A new perspective for sustainable agriculture". Soil and Tillage Research, 206 (in press).

[55] Blanco-Canqui H., Shaver T.M., Lindquist J.L., Shapiro C.A., Elmore R.W., Francis C.A., Hergert G.W. (2015). "Cover crops and ecosystem services: insights from studies in temperate soils". Agronomy Journal, 107, (pp. 2449).

[56] Devedee A.K. and Parihar R.K. (2018). "Agricultural waste / stubble management (waste to wealth), alternative to burning". Agribios Newsletter, 16(10): (pp. $43-45$ ).

[57] Sindhu R., Binod P. and Pandey (2016). "A novel sono-assisted acid pretreatment of chili post harvest residue for bioethanol production". Bioresource Technology, 213, (pp. 58-63). 